\title{
Planktotalea frisia gen. nov., sp. nov., isolated from the southern North Sea
}

\author{
Sarah Hahnke, ${ }^{1}$ Brian J. Tindall, ${ }^{2}$ Peter Schumann, ${ }^{2}$ Martin Sperling, ${ }^{1} \dagger$ \\ Thorsten Brinkhoff ${ }^{1}$ and Meinhard Simon ${ }^{1}$
}

Correspondence

Meinhard Simon

m.simon@icbm.de

\author{
${ }^{1}$ Institute for Chemistry and Biology of the Marine Environment (ICBM), University of Oldenburg, \\ D-26111 Oldenburg, Germany \\ ${ }^{2}$ DSMZ - Deutsche Sammlung von Mikroorganismen und Zellkulturen, Inhoffenstraße 7B, \\ D-38124 Braunschweig, Germany
}

\begin{abstract}
A heterotrophic, aerobic bacterium, designated strain $\mathrm{SH} 6-1^{\top}$, was obtained from a seawater sample collected from the open North Sea during a phytoplankton bloom. Strain $\mathrm{SH} 6-1^{\top}$ was isolated from a $10^{-6}$ dilution culture, which indicated a high abundance of this organism in the environmental sample. $16 \mathrm{~S}$ rRNA gene sequence comparison revealed that strain $\mathrm{SH} 6-1^{\top}$ belonged to the marine Roseobacter clade (order Rhodobacterales) within the class Alphaproteobacteria. Pelagicola litoralis $\mathrm{CL}-\mathrm{ES} 2^{\top}$ was the closest phylogenetic neighbour (96.4\% 16S rRNA gene sequence similarity). Cells of strain SH6-1 ${ }^{\top}$ were small or elongated irregular rods. Optimal growth occurred between 20 and $25{ }^{\circ} \mathrm{C}$ and between $\mathrm{pH} 7.5$ and 9.0 with peptone and yeast extract. On marine agar, the isolate formed non-pigmented, small, circular, convex colonies. For growth, cells required sodium ions and the vitamins pantothenic acid and nicotinic acid amide. The DNA G $+\mathrm{C}$ content was $53.8 \mathrm{~mol} \%$. The fatty acids $(>1 \%)$ were $\mathrm{C}_{10: 0}$ $3-\mathrm{OH}, \mathrm{C}_{16: 0}, \mathrm{C}_{12: 1}, \mathrm{C}_{12: 1} 3-\mathrm{OH}, \mathrm{C}_{18: 0}, \mathrm{C}_{18: 1} \omega 7 c, \mathrm{C}_{18: 2}$ and 11-methyl $\mathrm{C}_{18: 1} \omega 7 c$. The polar lipid pattern indicated the presence of phosphatidylcholine, phosphatidylglycerol, an unidentified aminolipid and one unidentified phospholipid. The major respiratory lipoquinone was ubiquinone Q-10. Strain $\mathrm{SH}-1^{\top}$ contained the genes pufLM, which code for the bacterial photosynthesis reaction centre; however, no bacteriochlorophyll a could be detected. Physiological, genotypic and phenotypic differences from $P$. litoralis support the description of a novel genus and species, for which we suggest the name Planktotalea frisia gen. nov., sp. nov; the type strain of the type species is $\mathrm{SH} 6-1^{\top}\left(=\mathrm{DSM} 23709^{\top}=\mathrm{LMG} 25294^{\mathrm{T}}\right)$.
\end{abstract}

Bacteria of the Roseobacter clade within the Alphaproteobacteria have been detected in a large variety of marine habitats, often in high abundance. Currently, more than 40 described genera are considered to be members of the Roseobacter clade (Brinkhoff et al., 2008). They gain energy from a multitude of organic compounds and some members are capable of aerobic anoxygenic photosynthesis; however, they are all unable to grow autotrophically (for reviews, see Buchan et al. 2005; Wagner-Döbler \& Biebl, 2006). In pelagic habitats of the North Sea, roseobacters were found to constitute 5-24\% of DAPI cell counts (Eilers et al., 2001; Alderkamp et al., 2006).

tPresent address: GEOMAR Helmholtz Zentrum für Ozeanforschung, Düsternbrooker Weg 20, D24105 Kiel, Germany.

Abbreviation: Bchl, bacteriochlorophyll.

The GenBank/EMBL/DDBJ accession number for the $16 \mathrm{~S}$ rRNA gene sequence of strain $\mathrm{SH} 6-1^{\top}$ is FJ882052.

A supplementary figure is available with the online version of this paper.
Strain SH6- $1^{\mathrm{T}}$ was isolated from a water sample collected at $2 \mathrm{~m}$ depth on 12 May 2007 in the southern North Sea (54

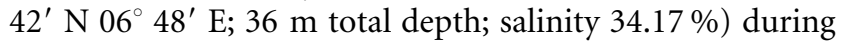
a phytoplankton bloom. In order to enrich the abundant bacteria present in the water sample, serial dilution cultures were used. Prior to inoculation of the serial dilution, the seawater sample was filtered through a $1.2-\mu \mathrm{m}$ filter to obtain single planktonic cells. Strain SH6-1 ${ }^{\mathrm{T}}$ was isolated from a $10^{-6}$ dilution in low-nutrient seawater medium (North Sea water filtered through $10 \mu \mathrm{m}$ and amended with $\left(1^{-1}\right) 5 \mathrm{mg}$ yeast extract and $10 \mathrm{mg}$ peptone; $\mathrm{pH} 8.0$; sterilized by autoclaving). After incubation in the dark at $15{ }^{\circ} \mathrm{C}$ for 4 weeks, $100 \mu \mathrm{l}$ of each dilution culture was spread on saltwater agar (SWM; containing $416 \mathrm{mM} \mathrm{NaCl}$, $49.2 \mathrm{mM} \mathrm{MgCl}_{2} \cdot 6 \mathrm{H}_{2} \mathrm{O}, 10 \mathrm{mM} \mathrm{CaCl} 2.2 \mathrm{H}_{2} \mathrm{O}, 8.9 \mathrm{mM}$ $\mathrm{KCl}, 28.2 \mathrm{mM} \mathrm{Na} \mathrm{SO}_{4}, 10 \mathrm{mM}$ HEPES, $840 \mu \mathrm{M} \mathrm{KBr}$, $400 \mu \mathrm{M} \mathrm{H} \mathrm{H}_{3} \mathrm{BO}_{3}, 150 \mu \mathrm{M} \mathrm{SrCl}, 400 \mu \mathrm{M} \mathrm{NH} \mathrm{NH}_{4} \mathrm{Cl}, 40 \mu \mathrm{M}$ $\mathrm{KH}_{2} \mathrm{PO}_{4}, 70 \mu \mathrm{M}$ NaF; $\mathrm{pH} 8.0$ ). The medium contained $30 \mathrm{mg}$ yeast extract and $60 \mathrm{mg}$ peptone $\left(\mathrm{l}^{-1}\right)$ as substrate and $20 \mathrm{~g}$ agar purified by washing five times in distilled 
water. After autoclaving, SWM was supplemented with $\left(1^{-1}\right) 1 \mathrm{ml}$ filter-sterilized trace element solution SL 10 (Tschech \& Pfennig, 1984), $1 \mathrm{ml}$ filter-sterilized 5-fold concentrated multivitamin solution (Balch et al., 1979) and $15 \mathrm{ml}$ of autoclaved $1 \mathrm{M} \mathrm{NaHCO}_{3}$. Plates were incubated at $15{ }^{\circ} \mathrm{C}$ in the dark. Single colonies were restreaked five times for purification. Unless otherwise stated, further cultivation and phenotypic tests were performed using SWM with $0.1 \mathrm{~g}$ yeast extract and $0.2 \mathrm{~g}$ peptone $\mathrm{l}^{-1}$.

Production of bacteriochlorophyll $a$ (Bchl $a$ ) was determined by spectrophotometric analysis. Cells grown in the dark were harvested by centrifugation at 10000 r.p.m. for $10 \mathrm{~min}$, and pigments were extracted with acetone/ methanol $(7: 2, \mathrm{v} / \mathrm{v})$ as described by Clayton (1966). The extract was examined for light absorbency (350-900 nm) with a Beckmann DU 520 general purpose UV/VIS spectrophotometer. Dinoroseobacter shibae DFL $12^{\mathrm{T}}$ (=DSM $16493^{\mathrm{T}}$ ) was used as a positive control.

The isolate was tested for growth at 4, 10, 17, 20, 25, 28, 30, $32,35,37,42$ and $45{ }^{\circ} \mathrm{C}$ and at $\mathrm{pH}$ 5-11 (in increments of $0.5 \mathrm{pH}$ units) with the $\mathrm{pH}$ adjusted with sterile $\mathrm{NaOH}$ and $\mathrm{HCl}$ solutions (Wagner-Döbler et al., 2004). It is known that the $\mathrm{pHs}$ of solutions $\mathrm{pH}>9.0$ do not remain stable because $\mathrm{CO}_{2}$, either in the air or from metabolic activity, dissolves in the medium and causes the $\mathrm{pH}$ to drop. Therefore, only growth during the first $48 \mathrm{~h}$ of incubation was considered. Clear differences could be detected and any growth after the first $48 \mathrm{~h}$ was scored as negative. Further growth experiments were performed in artificial seawater medium (ASW) according to Zech et al. (2009) with addition after autoclaving of $\left(1^{-1}\right) 15 \mathrm{ml}$ autoclaved $1 \mathrm{M}$ $\mathrm{NaHCO}_{3}$ and $1 \mathrm{ml}$ multivitamin solution, as above.

Growth with $0,12.5,25,37.5,50,65,80$ and $100 \mathrm{~g}$ salts $\mathrm{l}^{-1}$ was determined in test tubes. The test medium was made from a concentrated stock salt solution $\left(1^{-1}: 80 \mathrm{~g} \mathrm{NaCl}, 16 \mathrm{~g}\right.$ $\mathrm{Na}_{2} \mathrm{SO}_{4}, 1 \mathrm{~g} \mathrm{NH} \mathrm{NH}_{4} \mathrm{Cl}, 12 \mathrm{~g} \mathrm{MgCl}_{2} .6 \mathrm{H}_{2} \mathrm{O}, 2 \mathrm{~g} \mathrm{KCl}, 0.6 \mathrm{~g}$ $\mathrm{CaCl}_{2} \cdot 2 \mathrm{H}_{2} \mathrm{O}, 0.76 \mathrm{~g} \mathrm{NaHCO}_{3}$; autoclaved separately) and supplemented with $\left(\mathrm{l}^{-1}\right) \quad 0.2 \mathrm{~g} \mathrm{KH}_{2} \mathrm{PO}_{4}, 0.25 \mathrm{~g} \mathrm{NH}_{4} \mathrm{Cl}$, $0.05 \mathrm{~g}$ yeast extract, $0.05 \mathrm{~g}$ peptone, $1 \mathrm{ml}$ multivitamin solution, as above, and $1 \mathrm{ml}$ trace element solution (Zech et al., 2009). Before inoculation, cells were precultured in SWM and washed once with the lowest concentration of salt solution. Osmotolerance was studied using $\mathrm{NaCl}$ only, at $0.01,0.05,0.1,0.25,0.37,0.5,0.7,1.0,1.5$ and $2.0 \mathrm{M} \mathrm{NaCl}$, in a minimal medium $\left(1^{-1}: 1 \mathrm{~g}\right.$ magnesium acetate, $40 \mathrm{mg}$ yeast extract, $7 \mathrm{~g} \mathrm{MgSO}_{4} .7 \mathrm{H}_{2} \mathrm{O}, 0.2 \mathrm{~g} \mathrm{KH}_{2} \mathrm{PO}_{4}, 0.25 \mathrm{~g}$ $\mathrm{NH}_{4} \mathrm{Cl}, 3 \mathrm{~g} \mathrm{MgCl}_{2} .6 \mathrm{H}_{2} \mathrm{O}, 0.5 \mathrm{~g} \mathrm{KCl}, 0.15 \mathrm{~g} \mathrm{CaCl}_{2} .2 \mathrm{H}_{2} \mathrm{O}$, $0.3 \mathrm{~g} \mathrm{KHCO}_{3}$; autoclaved separately), with vitamins and trace elements as mentioned above for growth with salts.

To determine the maximal doubling time, growth in SWM under optimal conditions $\left(25{ }^{\circ} \mathrm{C}, \mathrm{pH} 7.5,3.75 \%\right.$ salt $)$ was done in triplicate. Every $1-2 \mathrm{~h}$, the test tubes were vigorously shaken and growth was monitored by measuring the $\mathrm{OD}_{600}$ (Spectronic 70 ) as a proxy for cell growth. Growth rates $(\mu)$ and doubling time $\left(t_{\mathrm{d}}=\ln 2 / \mu\right)$ were determined by linear regression of semi-logarithmic plots of cell density against time.

Requirement for single vitamins was tested in ASW supplemented with all 20 amino acids (each $1 \mathrm{mM}$ ) as the carbon source. Cells were precultured in SWM and washed with ASW without substrate prior to inoculation. All amino acids were added since strain SH6- ${ }^{\mathrm{T}}$ did not grow in minimal medium with single amino acids. The vitamins nicotinic acid amide, thiamine, pantothenic acid, pyridoxal hydrochloride, cyanocobalamin, riboflavin and biotin (all at $0.05 \mathrm{mg} \mathrm{l}^{-1}$ ) were tested in medium from which one was omitted.

Tests for growth on single substrates $\left(1 \mathrm{gl}^{-1}\right)$ were performed in ASW as described by Martens et al. (2006). Additionally, the algal osmolyte dimethylsulfoniopropionate $(100 \mu \mathrm{M})$ was tested. Utilization of amino acids was tested at a final concentration of $5 \mathrm{mM}$ except for tyrosine, which was added to $1 \mathrm{mM}$ because of precipitation at $5 \mathrm{mM}$. The $\mathrm{pH}$ was adjusted to 7.5. All of the test substrates are listed in the species description. Cells were precultured in SWM to exponential phase and washed twice with ASW without substrate in 2-ml reaction vessels. For each substrate, $5 \mathrm{ml}$ medium was inoculated in duplicate with $10 \mu \mathrm{l}$ washed cells. Since no or only very weak growth was observed on single substrates, assays were supplemented with $0.1 \mathrm{~g}$ yeast extract $\mathrm{l}^{-1}$, similarly to Wagner-Döbler et al. (2004). Cell cultures with $0.1 \mathrm{~g}$ yeast extract $1^{-1}$ were used as a negative control. Growth was determined after incubation at $20{ }^{\circ} \mathrm{C}$ for at least 1 week by an increase in $\mathrm{OD}_{600}$; growth was scored as negative when equal to or less than that in the negative control.

Gram staining was performed using the Hucker staining method, as described by Murray et al. (1994). To test for cytochrome oxidase, a single colony was streaked onto a cellulose strip saturated with test reagent $\left(1^{-1}: 1 \mathrm{~g}\right.$ ascorbic acid, $10 \mathrm{~g}$ tetramethyl- $p$-phenylenediamine- $\mathrm{HCl})$. Blue coloration showed oxidase activity (positive control Micrococcus luteus). To assay catalase reaction, a drop of $5 \%$ $\mathrm{H}_{2} \mathrm{O}_{2}$ was added to a dense cell culture. Escherichia coli was used as a positive control. Exoenzyme activities (hydrolysis of gelatin, starch and Tween 80) were analysed on SWM solidified with $9 \%(\mathrm{w} / \mathrm{v})$ gelatin or $1.5 \%(\mathrm{w} / \mathrm{v})$ agarose and supplemented with $0.2 \%(\mathrm{w} / \mathrm{v})$ starch or $1 \%(\mathrm{v} / \mathrm{v})$ Tween 80 (Smibert \& Krieg, 1994). Reduction of nitrate was tested in anoxic ASW containing $0.5 \mathrm{~g}$ resazurin $\mathrm{l}^{-1}$. After autoclaving, the medium was reduced by addition of $\sim 1 \mathrm{mg}$ sterile sodium dithionite (causing discoloration of the resazurin) and nitrate was added as 1 g sodium nitrate $1^{-1}$. The medium was placed into test tubes containing a small inverted glass tube, the headspace was flushed with $\mathrm{N}_{2} / \mathrm{CO}_{2}$ $(80: 20, \mathrm{v} / \mathrm{v})$ and the tubes were sealed. Substrates $\left(1^{-1}\right.$ : $0.2 \mathrm{~g}$ glucose and $0.1 \mathrm{~g}$ yeast extract) and sodium nitrate were injected from anoxic stock solutions. Cells were precultured in SWM to exponential phase under $\mathrm{N}_{2}$ before inoculation. Accumulation of bubbles in the inverted glass tube indicated $\mathrm{N}_{2}$ formation by nitrate reduction. Roseobacter denitrificans DSM $7001^{\mathrm{T}}$ was used as a positive 
control. Antibiotic susceptibility was tested by agar diffusion using penicillin $G$, streptomycin sulfate, chloramphenicol and kanamycin sulfate, as described in Brinkhoff et al. (2004). Phaeobacter gallaeciensis $\mathrm{BS} 107^{\mathrm{T}}$ and Rhodobacter sphaeroides Van Niel's ATH 2.4.1 ${ }^{\mathrm{T}}$ were used as controls. For transmission electron microscopy (TEM), cells were grown in SWM to exponential phase, washed once in distilled water, air dried on 200-mesh copper grids (Plano) and examined using a $902 \mathrm{~A}$ electron microscope (Zeiss), as described previously (Chávez et al., 2004).

Amplification and purification of the 16S rRNA gene were carried out as described by Brinkhoff \& Muyzer (1997) using the primer pair 27F (GM3F) and 1492R (GM4R). Sequencing was performed by GATC Biotech (Konstanz, Germany). Phylogenetic analysis was performed using the ARB software package (http://www.arb-home.de; Ludwig et al., 2004). Detection of genes encoding the subunits of the photosynthetic reaction centre complex ( $p u f L$ and pufM) was performed by PCR using the primers pufL forward (5'-CTKTTCGACTTCTGGGTSGG-3') and pufM reverse (5'-CCATSGTCCAGCGCCAGAA-3') (Béjà et al., 2002). Reactions were performed in an Eppendorf thermocycler with the following programme: $94{ }^{\circ} \mathrm{C}$ for $3 \mathrm{~min}, 30$ cycles at $94{ }^{\circ} \mathrm{C}$ for $1 \mathrm{~min}, 60{ }^{\circ} \mathrm{C}$ for $1 \mathrm{~min}$ and $72{ }^{\circ} \mathrm{C}$ for $1 \mathrm{~min}$ and a final extension step at $72{ }^{\circ} \mathrm{C}$ for $10 \mathrm{~min}$. Amplification products were purified using the peqGOLD MicroSpin Cycle-Pure kit (PEQLAB Biotechnologie, Erlangen, Germany) and sequenced at GATC Biotech.

For the following analyses, cell biomass of strain SH6- ${ }^{\mathrm{T}}$ and Pelagicola litoralis CL-ES2 ${ }^{\mathrm{T}}$ was obtained from cells cultivated in SWM to exponential phase at $20{ }^{\circ} \mathrm{C}$. Respiratory lipoquinones and polar lipids were extracted from $100 \mathrm{mg}$ freeze-dried cells using the method described by Tindall (1990a, b). Respiratory lipoquinones were separated into their structural classes by TLC. Bands were eluted and further separated and identified by HPLC using an $\mathrm{RP}_{18}$ column (Tindall, 1996). Polar lipids were separated by twodimensional chromatography and identified on the basis of their $R_{\mathrm{F}}$ values in combination with their reaction with specific staining reagents (Tindall, 1990a, b). Fatty acid methyl esters were released from $10 \mathrm{mg}$ freeze-dried cells using methodologies that release only ester-linked fatty acids or ester- and amide-linked fatty acids (Labrenz et al., 1998; Strömpl et al., 1999). Initially, the samples were analysed using the MIDI Sherlock system version 6 and the TSBA40 peak naming tables. Peaks that were not identified or were not unambiguously identified by the MIDI Sherlock system were further characterized by GC-MS using a Varian CP3800 GC coupled to a Varian 320-MS single quadrupole MS in electron impact mode. The DNA G $+\mathrm{C}$ content of strain SH6- $1^{\mathrm{T}}$ was determined by extracting genomic DNA according to Cashion et al. (1977) and subsequently determining the deoxyribonucleosides by HPLC (Mesbah et al., 1989; Tamaoka \& Komagata, 1984).

After 7 days on SWM at $20{ }^{\circ} \mathrm{C}$, colonies were circular, convex and whitish with a shiny surface and up to $0.5 \mathrm{~mm}$ in diameter. Single cells grown in liquid medium were short rods to irregular elongated rods with a length of $0.5-$ $4.0 \mu \mathrm{m}$ and a width of $0.5-1.0 \mu \mathrm{m}$ (Fig. S1, available in IJSEM Online). Cells were Gram-negative. Flagella were not detected by microscopy and the cells did not show clear motility; however, the cells exhibited slight wobbling.

Strain SH6- $1^{\mathrm{T}}$ grew at $4-32{ }^{\circ} \mathrm{C}$ (optimum $20-25^{\circ} \mathrm{C}$ ), at pH 6.0-9.5 (optimum pH 7.5-9.0) and with $1.25-8.0 \%$ salt (optimum $3.75 \%$ salt). The isolate had an absolute requirement for $\mathrm{Na}^{+}$and its osmotolerance ranged from 0.25 to $0.7 \mathrm{M} \mathrm{NaCl}$. Under optimum conditions in SWM, the doubling time was $3.7 \mathrm{~h}$. Strain $\mathrm{SH} 6-\mathrm{1}^{\mathrm{T}}$ showed no or only very weak growth on minimal medium; however, growth was stimulated with the addition of $0.1 \mathrm{~g}$ yeast extract $\mathrm{l}^{-1}$. The following carbon sources supported cell growth: L-alanine, Larginine, L-aspartic acid, L-proline, L-serine, L-tryptophan, L-tyrosine, (+ )-D-xylose, ( + )-D-glucose, (+)-D-mannose, $(+)$-D-galactose, (-)-D-fructose, (-)-D-ribose, (-)-D-mannitol, sucrose, maltose, cellobiose, trehalose, lactose, sodium acetate, sodium pyruvate, sodium malate, citric acid, disodium succinate, sodium lactate, glycerol and Tween 80 . No growth was observed in the absence of vitamins. Strain SH6- $1^{\mathrm{T}}$ was dependent on pantothenic acid and nicotinic acid amide. Cells were susceptible to penicillin G, streptomycin sulfate and chloramphenicol, but not to kanamycin sulfate. The isolate exhibited oxidase, but not catalase activity.

Analysis of the $16 \mathrm{~S}$ rRNA gene sequence indicated that strain SH6- $1^{\mathrm{T}}$ shared $96.4 \%$ sequence similarity with $P$. litoralis CL-ES2 ${ }^{\mathrm{T}}$, its nearest described relative (Kim et al., 2008; Fig. 1). The DNA G $+\mathrm{C}$ content of strain $\mathrm{SH} 6-1^{\mathrm{T}}$ was 53.8 mol\%. Cells contained the genes pufLM for the bacterial photosynthesis reaction centre; however, in laboratory cultures, no Bchl $a$ or any other pigments could be detected.

The predominant respiratory lipoquinone of strain SH6- $1^{\mathrm{T}}$ was ubiquinone Q-10. The fatty acid composition was dominated by $\mathrm{C}_{18: 1} \omega 7 c$, other fatty acids were $\mathrm{C}_{10: 0} 3-\mathrm{OH}$, $\mathrm{C}_{16: 0}, \mathrm{C}_{12: 1}, \mathrm{C}_{12: 1}$ 3-OH, $\mathrm{C}_{16: 0}, \mathrm{C}_{18: 0}, \mathrm{C}_{18: 2}$, 11-methyl $\mathrm{C}_{18: 1} \omega 7 c$ and summed feature 7 (comprising $\mathrm{C}_{19: 1} \omega 6 c$ and/or unknown ECL 18.846) (Table 1). The fatty acid compositions of strain SH6- $1^{\mathrm{T}}$ and $P$. litoralis CL-ES2 ${ }^{\mathrm{T}}$ showed some differences in fatty acids that were present in low concentrations. P. litoralis CL-ES2 ${ }^{\mathrm{T}}$ contained $\mathrm{C}_{16: 0} 2$ $\mathrm{OH}$, which was not present in strain $\mathrm{SH} 6 \mathrm{-}^{\mathrm{T}}$, and much larger amounts of $\mathrm{C}_{14: 1} 3-\mathrm{OH}$ than strain $\mathrm{SH} 6-1^{\mathrm{T}}$. Strain SH6- $1^{\mathrm{T}}$, however, contained $\mathrm{C}_{12: 1} 3-\mathrm{OH}$, which was not present in $P$. litoralis CL-ES2 ${ }^{\mathrm{T}}$.

The polar lipids of strain SH6- $1^{\mathrm{T}}$ were phosphatidylcholine, phosphatidylglycerol, one unidentified aminolipid and one unidentified phospholipid. Comparison of the polar lipid patterns of the isolate with the reference strain revealed clear differences (Fig. 2). Further differential characteristics of strain SH6- $1^{\mathrm{T}}$ and $P$. litoralis $\mathrm{CL}-\mathrm{ES} 2^{\mathrm{T}}$ are summarized in Table 2.

On the basis of the distinctive features presented here, we propose that strain $\mathrm{SH} 6-1^{\mathrm{T}}$ be assigned to a new genus as a 


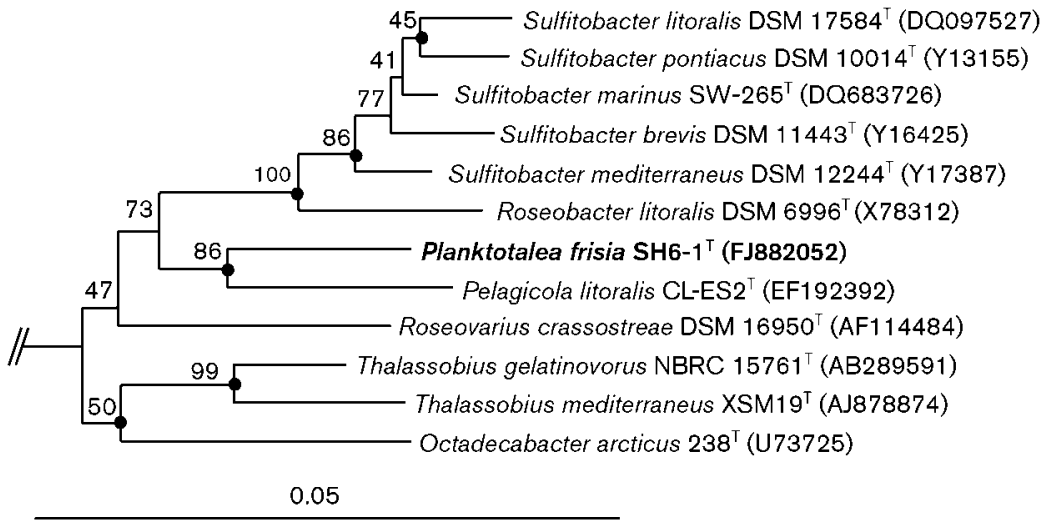

Fig. 1. Neighbour-joining tree based on $16 \mathrm{~S}$ rRNA gene sequences showing the phylogenetic relationships between strain $\mathrm{SH} 6-1^{\top}$ and representatives of the family Rhodobacteraceae within the class Alphaproteobacteria. Bootstrap values based on 1000 replicates are shown at branch nodes. Filled circles indicate that the corresponding nodes were also recovered in trees generated with the maximum-likelihood method. Selected members of the class Gammaproteobacteria were used as an outgroup (not shown). Bar, $5 \%$ sequence divergence.

representative of a novel species, for which the name Planktotalea frisia gen. nov., sp. nov. is proposed.

\section{Description of Planktotalea gen. nov.}

Planktotalea (Plank.to.ta'le.a. Gr. adj. planktos roaming, wandering; L. fem. n. talea a slender staff, a rod; N.L. fem. n. Planktotalea a planktonic/roaming rod).

Gram-negative, aerobic, oxidase-positive and catalase-negative. Cells are small to irregular rods $(0.5-4.0 \mu \mathrm{m}$ long and $0.4-1.0 \mu \mathrm{m}$ wide). Contains pufLM, the genes that encode subunits of the bacterial photosynthetic reaction centre complex. Growth in minimal medium on single substrates is poor. Cells require vitamins as well as sodium ions. The major respiratory lipoquinone is Q-10. The polar lipids are phosphatidylcholine, phosphatidylglycerol, an unidentified aminolipid and an unidentified phospholipid. The major fatty acids $(>1 \%)$ are $\mathrm{C}_{10: 0} 3-\mathrm{OH}, \mathrm{C}_{12: 1}, \mathrm{C}_{12: 1} 3-\mathrm{OH}$,
$\mathrm{C}_{16: 0}, \mathrm{C}_{18: 0}, \mathrm{C}_{18: 1} \omega 7 c, \mathrm{C}_{18: 2}, 11$-methyl $\mathrm{C}_{18: 1} \omega 7 c$ and summed feature 7 (comprising $\mathrm{C}_{19: 1} \omega 6 \mathrm{c}$ and/or unknown ECL 18.846); traces of $\mathrm{C}_{14: 1} 3-\mathrm{OH}$ are also found. Whereas most of the fatty acids were ester-linked, a small amount of $\mathrm{C}_{14: 1} 3-\mathrm{OH}$ was amide-linked. The genus is a member of the class Alphaproteobacteria, order Rhodobacterales. The type, and only, species is Planktotalea frisia.

\section{Description of Planktotalea frisia sp. nov.}

Planktotalea frisia (fri'si.a. L. fem. adj. frisia Frisian, pertaining to Frisia, a coastal region along the south-eastern corner of the North Sea, i.e. the German Bight, from where the organism was obtained).

Has the following characteristics in addition to those given in the genus description. On SWM, colonies are small, circular, convex and whitish with a shiny surface and up to

Table 1. Fatty acid compositions of strain $\mathrm{SH} 6-1^{\top}$ and Pelagicola litoralis $\mathrm{CL}-\mathrm{ES} 2^{\top}$, using methodologies which release only ester-linked (M1) or ester- and amide-linked (M2) fatty acids

-, Not detected.

\begin{tabular}{|c|c|c|c|c|}
\hline \multirow[t]{2}{*}{ Fatty acid } & \multicolumn{2}{|c|}{ SH6-1 ${ }^{\mathrm{T}}$} & \multicolumn{2}{|c|}{ P. litoralis CL-ES2 ${ }^{\mathrm{T}}$} \\
\hline & M1 & M2 & M1 & M2 \\
\hline$C_{16: 0}$ & 2.44 & 6.44 & 2.91 & 3.26 \\
\hline$C_{18: 0}$ & 2.57 & 1.75 & 0.75 & 0.70 \\
\hline $\mathrm{C}_{12: 1^{*}}$ & 1.68 & 2.56 & 2.24 & 2.46 \\
\hline $\mathrm{C}_{18: 1} \omega 7 \mathrm{c}$ & 75.36 & 70.97 & 75.91 & 71.31 \\
\hline$C_{18: 2^{*}}$ & 10.34 & 11.45 & 10.09 & 9.54 \\
\hline $\mathrm{C}_{10: 0} 3-\mathrm{OH}$ & 1.54 & 1.36 & 4.01 & 3.37 \\
\hline $\mathrm{C}_{12: 1} 3-\mathrm{OH}$ & 2.53 & 1.82 & - & - \\
\hline $\mathrm{C}_{14: 1} 3-\mathrm{OH}^{*}$ & - & 0.18 & - & 2.67 \\
\hline $\mathrm{C}_{16: 0} 2-\mathrm{OH}$ & - & - & 1.13 & 1.11 \\
\hline 11-Methyl $C_{18: 1} \omega 7 c$ & 2.29 & 2.74 & 2.96 & 2.73 \\
\hline Summed feature $7 \dagger$ & 1.18 & 0.34 & - & 0.14 \\
\hline
\end{tabular}

*The fatty acid is not listed in the MIDI Sherlock TSBA40 peak naming table and its identity was confirmed by GC-MS.

$\dagger$ Summed features represent two or three fatty acids that cannot be separated by the Microbial Identification System. Summed feature 7 consisted of $C_{19: 1} \omega 6 c$ and/or unknown ECL 18.846. 


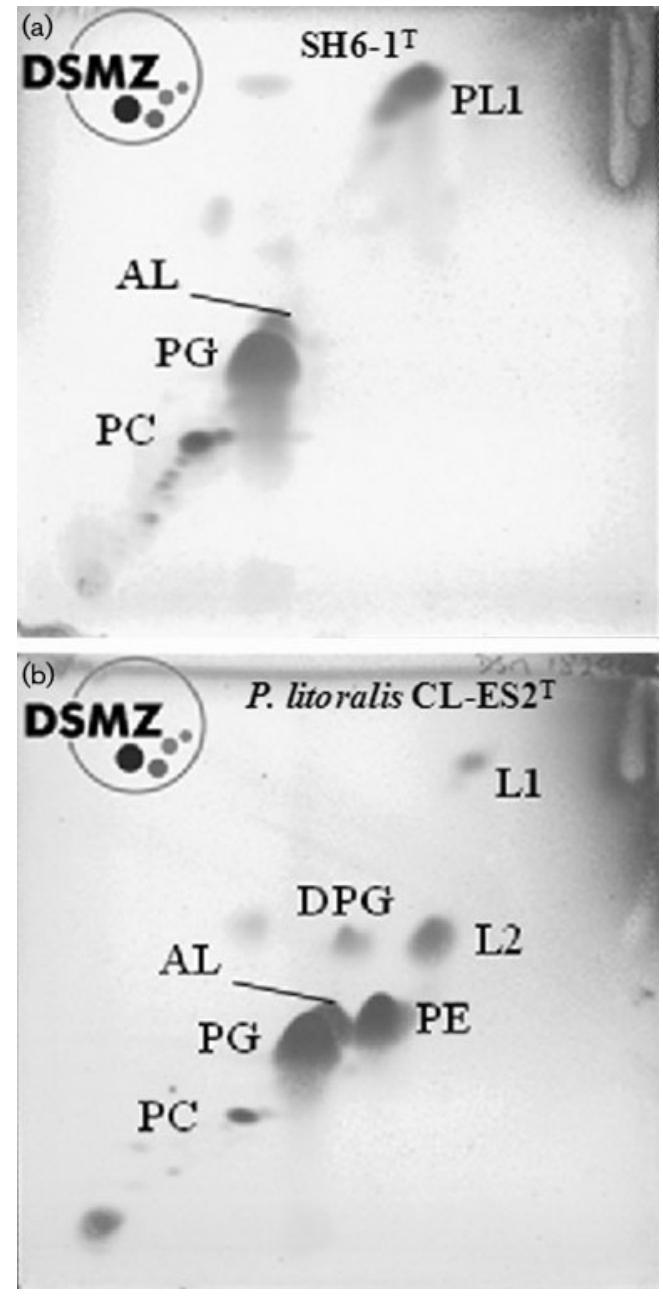

Fig. 2. Polar lipid profiles of strain $\mathrm{SH} 6-1^{\top}$ (a) and Pelagicola litoralis $\mathrm{CL}-E S 2^{\top}$ (b). AL, Unidentified aminolipid; DPG, diphosphatidylglycerol; L, lipid; PC, phosphatidylcholine; PE, phosphatidylethanolamine; PG, phosphatidylglycerol; PL, phospholipid.

$1 \mathrm{~mm}$ in diameter. Grows at $4-32{ }^{\circ} \mathrm{C}$ (optimum $20-25{ }^{\circ} \mathrm{C}$ ) and at $\mathrm{pH}$ 6.0-9.5 (optimum $\mathrm{pH}$ 7.5-9.0). Grows with 1.25$8.00 \%$ salt (optimum $3.75 \%$ salt). Has an absolute requirement for $\mathrm{Na}^{+}$; osmotolerance ranges from 0.25 to $0.70 \mathrm{M} \mathrm{NaCl}$. Does not grow without the vitamins pantothenic acid and nicotinic acid amide. Does not reduce nitrate to $\mathrm{N}_{2}$. Does not hydrolyse gelatin or starch, but is able to hydrolyse Tween 80 . In ASW with $0.1 \mathrm{~g}$ yeast extract $\mathrm{l}^{-1}$, utilizes L-alanine, L-arginine, L-aspartic acid, L-proline, Lserine, L-tryptophan, L-tyrosine, (+)-D-xylose, $(+)$-D-glucose, $(+)$-D-mannose, $\quad(+)$-D-galactose, (-)-D-fructose, $\quad(-)$-Dribose, (-)-D-mannitol, sucrose, maltose, cellobiose, trehalose, lactose, sodium acetate, sodium pyruvate, sodium malate, citric acid, disodium succinate, sodium lactate, glycerol and Tween 80, but not L-asparagine, L-cysteine, L-glutamine, L-glutamic acid, glycine, L-histidine, L-isoleucine, L-leucine, L-lysine, Lmethionine, L-phenylalanine, L-threonine, L-valine, $(+)$-Larabinose, (+)-L-rhamnose, (-)-L-fucose, (-)-D-sorbitol,
Table 2. Differential characteristics of strain $\mathrm{SH} 6-1^{\top}$ and Pelagicola litoralis CL-ES2 ${ }^{\top}$

Data were taken from this study and (Kim et al., 2008). Both strains were rods and formed circular and convex colonies. +, Positive; $\mathrm{W}$, weakly positive $\left(\mathrm{OD}_{600} \leqslant 0.2\right) ;-$, negative; $\mathrm{ND}$, no data available.

\begin{tabular}{|c|c|c|}
\hline Characteristic & SH6-1 ${ }^{\mathrm{T}}$ & $\begin{array}{l}\text { P. litoralis } \\
\text { CL-ES2 }^{\mathrm{T}}\end{array}$ \\
\hline Colony colour & Whitish & Creamy \\
\hline Cell shape & Irregular & Club-shaped \\
\hline Cell size $(\mu \mathrm{m})$ & $0.5-4 \times 0.5-1.0$ & $1.1-7.0 \times 0.5-1.4$ \\
\hline Motility & Slight & - \\
\hline pufLM & + & ND \\
\hline Catalase & - & + \\
\hline Growth at $4{ }^{\circ} \mathrm{C}$ & + & - \\
\hline DNA G $+\mathrm{C}$ content $(\mathrm{mol} \%)$ & 53.8 & 47 \\
\hline \multicolumn{3}{|l|}{ Salinity (\%) } \\
\hline Range & $1.25-8.00$ & $2-6$ \\
\hline Optimum & 3.75 & $3-4$ \\
\hline Osmotolerance $(\mathrm{NaCl} ; \mathrm{M})$ & $0.25-0.70$ & ND \\
\hline \multicolumn{3}{|l|}{ Growth temperature $\left({ }^{\circ} \mathrm{C}\right)$} \\
\hline Range & $4-32$ & $20-30$ \\
\hline Optimum & $20-25$ & 25 \\
\hline \multicolumn{3}{|l|}{ Growth $\mathrm{pH}$} \\
\hline Range & $6.0-9.5$ & $6.0-8.0$ \\
\hline Optimum & $7.5-9.0$ & 7.0 \\
\hline \multicolumn{3}{|l|}{ Utilization of: } \\
\hline Proline & $\mathrm{W}$ & + \\
\hline Serine & $\mathrm{W}$ & + \\
\hline Citrate & $\mathrm{w}$ & - \\
\hline Sucrose & $\mathrm{W}$ & - \\
\hline Trehalose & $\mathrm{w}$ & - \\
\hline Succinate & $\mathrm{W}$ & - \\
\hline Pyruvate & $\mathrm{w}$ & - \\
\hline Glycerol & $\mathrm{W}$ & - \\
\hline \multicolumn{3}{|l|}{ Hydrolysis of: } \\
\hline Starch & - & + \\
\hline Tween 80 & $\mathrm{~W}$ & + \\
\hline
\end{tabular}

(+)-D-glucosamine, laminarin, starch, inulin, xylan, sodium formate, sodium propionate or dimethylsulfoniopropionate. In laboratory culture, does not express Bchl $a$ or any other pigments.

The type strain, SH6- $1^{\mathrm{T}}\left(=\mathrm{DSM} 23709^{\mathrm{T}}=\mathrm{LMG} 25294^{\mathrm{T}}\right)$, was isolated from water from a North Sea sample taken at a depth of $2 \mathrm{~m}$. The DNA G $+\mathrm{C}$ content of the type strain is $53.8 \mathrm{~mol} \%$. The type strain is susceptible to penicillin G, streptomycin sulfate and chloramphenicol, but resistant to kanamycin sulfate.

\section{Acknowledgements}

We thank Heike Oetting for technical assistance with the transmission electron microscopy and Thomas Langer for carrying out growth experiments with different vitamin mixtures. This work was supported 
by the Lower Saxonian Volkswagen Foundation (VW-Vorab) within the Lower Saxonian-Israeli joint program.

\section{References}

Alderkamp, A. C., Sintes, E. \& Herndl, G. J. (2006). Abundance and activity of major groups of prokaryotic plankton in the coastal North Sea during spring and summer. Aquat Microb Ecol 45, 237-246.

Balch, W. E., Fox, G. E., Magrum, L. J., Woese, C. R. \& Wolfe, R. S. (1979). Methanogens: reevaluation of a unique biological group. Microbiol Rev 43, 260-296.

Béjà, O., Suzuki, M. T., Heidelberg, J. F., Nelson, W. C., Preston, C. M., Hamada, T., Eisen, J. A., Fraser, C. M. \& DeLong, E. F. (2002). Unsuspected diversity among marine aerobic anoxygenic phototrophs. Nature 415, 630-633.

Brinkhoff, T. \& Muyzer, G. (1997). Increased species diversity and extended habitat range of sulfur-oxidizing Thiomicrospira spp. Appl Environ Microbiol 63, 3789-3796.

Brinkhoff, T., Bach, G., Heidorn, T., Liang, L., Schlingloff, A. \& Simon, M. (2004). Antibiotic production by a Roseobacter clade-affiliated species from the German Wadden Sea and its antagonistic effects on indigenous isolates. Appl Environ Microbiol 70, 2560-2565.

Brinkhoff, T., Giebel, H.-A. \& Simon, M. (2008). Diversity, ecology, and genomics of the Roseobacter clade: a short overview. Arch Microbiol 189, 531-539.

Buchan, A., González, J. M. \& Moran, M. A. (2005). Overview of the marine Roseobacter lineage. Appl Environ Microbiol 71, 5665-5677.

Cashion, P., Holder-Franklin, M. A., McCully, J. \& Franklin, M. (1977). A rapid method for the base ratio determination of bacterial DNA. Anal Biochem 81, 461-466.

Chávez, F. P., Lünsdorf, H. \& Jerez, C. A. (2004). Growth of polychlorinated-biphenyl-degrading bacteria in the presence of biphenyl and chlorobiphenyls generates oxidative stress and massive accumulation of inorganic polyphosphate. Appl Environ Microbiol 70, 3064-3072.

Clayton, R. K. (1966). Spectroscopic analysis of bacteriochlorophylls in vitro and in vivo. Photochem Photobiol 5, 669-677.

Eilers, H., Pernthaler, J., Peplies, J., Glöckner, F. O., Gerdts, G. \& Amann, R. (2001). Isolation of novel pelagic bacteria from the German Bight and their seasonal contributions to surface picoplankton. Appl Environ Microbiol 67, 5134-5142.

Kim, Y.-G., Hwang, C. Y. \& Cho, B. C. (2008). Pelagicola litoralis gen. nov., sp. nov., isolated from coastal water in Korea. Int J Syst Evol Microbiol 58, 2102-2106.

Labrenz, M., Collins, M. D., Lawson, P. A., Tindall, B. J., Braker, G. \& Hirsch, P. (1998). Antarctobacter heliothermus gen. nov., sp. nov., a budding bacterium from hypersaline and heliothermal Ekho Lake. Int J Syst Bacteriol 48, 1363-1372.

Ludwig, W., Strunk, O., Westram, R., Richter, L., Meier, H., Yadhukumar, Buchner, A., Lai, T., Steppi, S. \& other authors (2004). ARB: a software environment for sequence data. Nucleic Acids Res 32, 1363-1371.
Martens, T., Heidorn, T., Pukall, R., Simon, M., Tindall, B. J. \& Brinkhoff, T. (2006). Reclassification of Roseobacter gallaeciensis RuizPonte et al. 1998 as Phaeobacter gallaeciensis gen. nov., comb. nov., description of Phaeobacter inhibens sp. nov., reclassification of Ruegeria algicola (Lafay et al. 1995) Uchino et al. 1999 as Marinovum algicola gen. nov., comb. nov., and emended descriptions of the genera Roseobacter, Ruegeria and Leisingera. Int J Syst Evol Microbiol 56, 1293-1304.

Mesbah, M., Premachandran, U. \& Whitman, W. B. (1989). Precise measurement of the $\mathrm{G}+\mathrm{C}$ content of deoxyribonucleic acid by high-performance liquid chromatography. Int J Syst Bacteriol 39, 159-167.

Murray, R. G. E., Doetsch, R. N. \& Robinow, C. F. (1994). Determinative and cytological light microscopy. In Methods for General and Molecular Bacteriology, pp. 21-41. Edited by P. Gerhardt, R. G. E. Murray, W. A. Wood \& N. R. Krieg. Washington, DC: American Society for Microbiology.

Smibert, R. M. \& Krieg, N. R. (1994). Phenotypic characterization. In Methods for General and Molecular Bacteriology, pp. 607-654. Edited by P. Gerhardt, R. G. E. Murray, W. A. Wood \& N. R. Krieg. Washington, DC: American Society for Microbiology.

Strömpl, C., Tindall, B. J., Jarvis, G. N., Lünsdorf, H., Moore, E. R. B. \& Hippe, H. (1999). A re-evaluation of the taxonomy of the genus Anaerovibrio, with the reclassification of Anaerovibrio glycerini as Anaerosinus glycerini gen. nov., comb. nov., and Anaerovibrio burkinabensis as Anaeroarcus burkinensis [corrig.] gen. nov., comb. nov. Int J Syst Bacteriol 49, 1861-1872.

Tamaoka, J. \& Komagata, K. (1984). Determination of DNA base composition by reversed-phase high-performance liquid chromatography. FEMS Microbiol Lett 25, 125-128.

Tindall, B. J. (1990a). A comparative study of the lipid composition of Halobacterium saccharovorum from various sources. Syst Appl Microbiol 13, 128-130.

Tindall, B. J. (1990b). Lipid composition of Halobacterium lacusprofundi. FEMS Microbiol Lett 66, 199-202.

Tindall, B. J. (1996). Respiratory lipoquinones as biomarkers. In Molecular Microbial Ecology Manual (section 4.1.5, suppl. 1). Edited by A. Akkermans, F. de Bruijn \& D. van Elsas. Dordrecht: Kluwer.

Tschech, A. \& Pfennig, N. (1984). Growth yield increase linked to caffeate reduction in Acetobacterium woodii. Arch Microbiol 137, 163-167.

Wagner-Döbler, I. \& Biebl, H. (2006). Environmental biology of the marine Roseobacter lineage. Annu Rev Microbiol 60, 255-280.

Wagner-Döbler, I., Rheims, H., Felske, A., El-Ghezal, A., FladeSchröder, D., Laatsch, H., Lang, S., Pukall, R. \& Tindall, B. J. (2004). Oceanibulbus indolifex gen. nov., sp. nov., a North Sea alphaproteobacterium that produces bioactive metabolites. Int J Syst Evol Microbiol 54, 1177-1184.

Zech, H., Thole, S., Schreiber, K., Kalhöfer, D., Voget, S., Brinkhoff, T., Simon, M., Schomburg, D. \& Rabus, R. (2009). Growth phasedependent global protein and metabolite profiles of Phaeobacter gallaeciensis strain DSM 17395, a member of the marine Roseobacterclade. Proteomics 9, 3677-3697. 